\title{
MIGRATION OF MELAMINE AND FORMALDEHYDE FROM KIDS' BAMBOO DINNER SETS
}

\author{
Svetla Petrova PETROVA ${ }^{\mathbf{1}}$, *Valentina CHRISTOVA - BAGDASSARIAN ${ }^{\mathbf{2}}$ \\ ${ }^{I}$ Food Composition and Consumer Products, National Center of Public Health and Analyses, Sofia, Bulgaria, \\ s.chavdarova@ncpha.government.bg \\ ${ }^{2}$ Food Composition and Consumer Products, National Center of Public Health and Analyses, Sofia, Bulgaria, \\ v.hristova@ncpha.government.bg \\ *Corresponding author \\ Received $12^{\text {th }}$ March 2021, accepted $28^{\text {th }}$ June 2021
}

\begin{abstract}
:
In recent years, products resembling the composition and / or appearance of plastic materials have been available on the market, which are actually made of a material containing various fillers and additives, such as melamine-formaldehyde resin, bamboo flour and other substances. They are advertised as natural bamboo, environmentally friendly and safe. The migration of melamine and formaldehyde from melamine-formaldehyde resin to food is possible. Melamine and formaldehyde are authorized substances in the EU for use in food contact materials under Regulation (EU) 10/2011. In 2019, melamine was classified as a possible human carcinogen by the IARC. It is toxic and increases the risk of kidney cancer. In 2012, formaldehyde was classified as carcinogenic to humans by the IARC. It could damage the central nervous system and especially the upper colic of the visual nervous system.

The purpose of this study is to determine whether there is a migration of melamine and formaldehyde from kids' bamboo dinner sets offered on the Bulgarian market and thus to prove the presence of melamine-formaldehyde resin in their composition.

A total of 24 samples - 6 bamboo sets, consisting of 4 items - bowls, cups, plates and utensils (fork and spoon) were analyzed. Standardized methods HPLC-UV DD CEN/TS 13130-27:2005 for melamine and spectrophotometric DD CEN/TS 13130-23:2005 for formaldehyde were used.

Migration of melamine and formaldehyde from all tested products was found. Melamine migration exceeds the specific migration limit (SML) in 62\% of products, and the highest value reaches 2.6 times $S M L$. All results of formaldehyde are within the EU legislation permissible values. The material from which the bamboo products are made must be classified as plastic, as it contains melamineformaldehyde resin. The results also show significant inhomogeneity of the composite material both within a batch and between batches.
\end{abstract}

Keywords: food contact materials, specific migration, melamine, formaldehyde, bamboo sets

\section{Introduction}

Bamboos (Bambuseae) are a subfamily Bambusoideae of the flowering perennial evergreen plant in the grass family Poaceae. Their homeland is Asia. About 91 genera and 1000 species of bamboo are known [1].
Bamboo is a fast-growing grass and can be cut without killing the plant. The chemical composition of bamboo determines its properties and uses. Over $90 \%$ of the total mass of bamboo consists of cellulose, hemicellulose and lignin, and the remaining up to $10 \%$ are resins, tannins, waxes and inorganic salts. 
Bamboo is used as a material for making various dishes and utensils. Its environmental characteristics are the main reason bamboo kitchen utensils have become popular and widely used. They are ideal for picnics, camping and travel. They are sought after for their strength, durability and biodegradability. They are more durable than wood and plastic. In addition, they are smooth and light, more resistant to heat and water. They do not absorb odors and are easy to clean. Bamboo dishes are easy to colour and decorate. This makes them attractive to consumers, giving a natural touch to any kitchen.

In recent years, items resembling the composition and/or appearance of plastic materials have been available on the market. These items are similar to kitchen melamine dishes, but are more matte. These include various bowls, cups, plates and cutlery. Some of them consist of melamine plastic as the main structural component, but also contain fillers ground bamboo ("bamboo-melamine"), corn flour and other similar ingredients. Other items may include bamboo fibers and polymer resin as a binder to form a composite product. A number of such bamboo-melamine food contact items are sold with the claim of being recyclable and natural. They are labeled and marketed as "biodegradable", "environmentally friendly", "organic" or "natural" or even in some cases "100\% bamboo" (Figure 1).

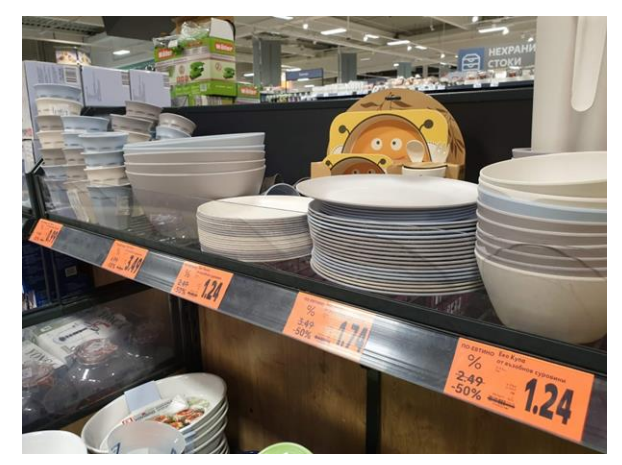

Fig.1. "Bamboo" dishes offered in a large food chain
In fact, so-called "bamboo" kitchen utensils are made of a material containing various fillers and additives, such as melamine-formaldehyde resin, bamboo and/or corn flour and other substances often not described on the label, so their composition is unknown.

\section{Melamine-formaldehyde resin}

Melamine-formaldehyde resin is a polymeric material (Figure 2), which is obtained in the process of polymerization of melamine and formaldehyde.

Melamine-formaldehyde resin is used as a filler in bamboo tableware. Migration of melamine and formaldehyde into the food could occur through use of such items in microwave ovens or due to cooker. Such migration could also be the result of production problems and defects, e.g. incomplete polycondensation during polymer production, injury and/or scratching of surfaces during molding.

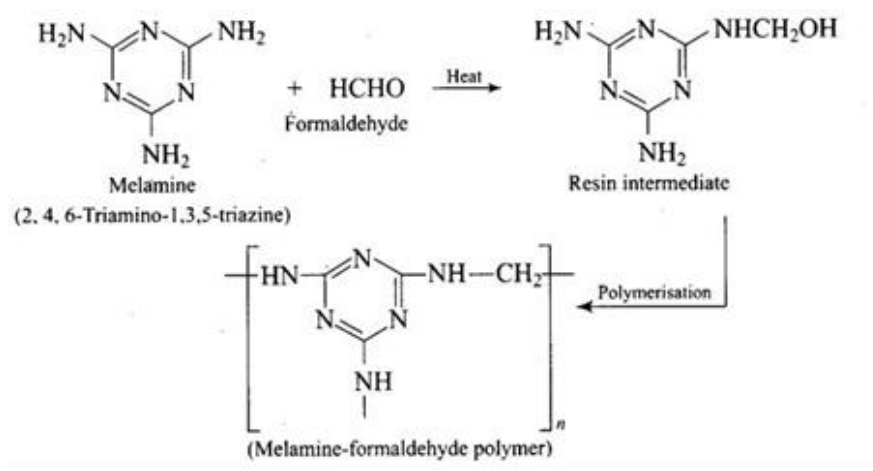

Fig. 2. Preparation of melamine-formaldehyde resin

A study by the Federal Institute for Risk Assessment in Germany (BfR) shows that the use of melamine tableware at high temperatures and heating in microwave ovens leads to a risk of increased migration of melamine and formaldehyde. Factors favoring the increase of migration are scratching, disruption of the surface of the kitchenware and their use in an acidic environment [2]. 


\section{Legislation}

Bamboo is not included in the list of permitted monomers, but it is a natural polymeric substance. The use of natural additives, such as bamboo in a plastic matrix, may not necessarily pose a direct health risk [3]. However, migration of melamine and formaldehyde is possible from dishes containing melamineformaldehyde resin [2].

Melamine (FCM № 239) and formaldehyde (FCM № 98) are authorized substances in the EU [3] for use in the manufacturing of plastic food contact materials. However, they are subject to restrictions, with specific migration limits (SMLs) of $15 \mathrm{mg} / \mathrm{kg}$ for formaldehyde (expressed as total formaldehyde and hexamethylenetetramine) and $2.5 \mathrm{mg} / \mathrm{kg}$ for melamine [4].

The requirement (see: Article 3 (2) of Regulation (EC) № 1935/2004 [5]) is that the labeling, advertising and presentation of a material or article does not mislead consumers. Therefore, manufacturers guarantee the actual composition of kitchen utensils through correct labeling and advertising in their marketing.

Due to the increased number of reports of high levels of migration of formaldehyde and melamine from melamine plastic products, Commission Regulation (EU) № 284/2011 [6] has been introduced. This regulation lays down specific conditions and detailed procedures for the import of plastic melamine kitchenware originating in the People's Republic of China and Hong Kong.

Since the beginning of 2020, the RASFF (Rapid Alert System for Food and Feed) has received reports of established high levels of migration of melamine and formaldehyde from bamboo products intended for food contact, mostly imported from China (Table 1). The migration of melamine of $28.5 \mathrm{mg} / \mathrm{kg}$ (reported by Germany) exceeds 11.4 times the specific migration limit of the monomer. Migration of formaldehyde of $269.0 \mathrm{mg} / \mathrm{kg}$ (reported by Switzerland) is 18 times the SML for formaldehyde. These data raise concern about the items available on the European market.

Table 1.

Notification for migration of melamine and formaldehyde according to RASFF - the system for the period January - October 2020.

\begin{tabular}{|c|c|c|c|c|c|}
\hline Country & Month 2020 & Bamboo item & Country of origin & $\begin{array}{l}\text { Melamine, } \mathrm{m} \\
\mathrm{g} / \mathrm{kg}\end{array}$ & $\begin{array}{l}\text { Formaldehyde, } \\
\mathrm{mg} / \mathrm{kg}\end{array}$ \\
\hline \multirow{3}{*}{ Germany } & April & Set of utensils & France & 28.5 & 12.2 \\
\hline & May & Cups & $\begin{array}{ll}\text { China } & \text { via } \\
\text { Netherlands } & \\
\end{array}$ & 4.3 & 15.7 \\
\hline & October & Bowls & Austria & 4.2 & 239.0 \\
\hline Poland & January & Bowls & China & - & 188.2 \\
\hline $\begin{array}{l}\text { Czech } \\
\text { Republic }\end{array}$ & May & $\begin{array}{l}\text { Kids' bamboo } \\
\text { dinner sets }\end{array}$ & China & 5.5 & 23.4 \\
\hline France & February & $\begin{array}{l}\text { Kids' bamboo } \\
\text { dinner sets }\end{array}$ & $\begin{array}{ll}\text { China } & \text { via } \\
\text { Belgium } & \\
\end{array}$ & 4.71 & 19.2 \\
\hline Lithuania & September & $\begin{array}{l}\text { Bamboo cups for } \\
\text { travel }\end{array}$ & China via Poland & 2,52 & - \\
\hline Switzerland & September & Bamboo bowls & Hong Kong & - & 269.0 \\
\hline \multirow[t]{2}{*}{ Portugal } & April & Bowls & China & 3.81 & - \\
\hline & May & Bowls & China & 5.5 & 16.37 \\
\hline Greece & March & Food boxes & China & 16.7 & 48.4 \\
\hline
\end{tabular}

Svetla Petrova PETROVA, Valentina CHRISTOVA - BAGDASSARIAN, Migration of melamine and formaldehyde from kids' bamboo dinner sets, Food and Environment Safety, Volume XX, Issue 2-2021, pag. 128 - 136 


\section{Melamine and formaldehyde - characteristics, health risks}

Melamine $\left(\mathrm{C}_{3} \mathrm{H}_{6} \mathrm{~N}_{6}\right)$ (Fig. 3) is an aromatic compound known as IUPAC 2,4,6-triamino-1,3,5-triazine. It is a colorless crystal, insoluble in water and slightly soluble in most organic solvents.

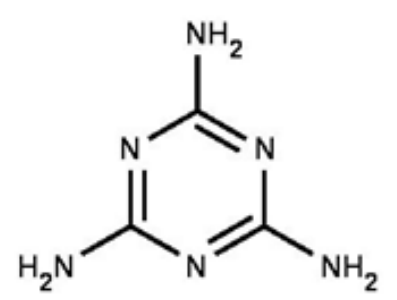

Fig. 3. Chemical structure of melamine

Melamine shows low acute toxicity in experiments with animals. The potential risk to human and animal health is associated with melamine's ability to form uric acid complexes, leading to the formation of crystals in the urine and severe kidney damage. Melamine is toxic to the kidneys and increases the risk of kidney cancer. It is harmless in low single doses, but at high levels and in combination with its analogues such as cyanuric acid, the health risk becomes significant [7]. Melamine has adverse effects on the male reproductive system, including testicles and sperm morphology at doses between 5 and $25 \mathrm{mg} / \mathrm{kg}$ body weight [8]. In 2019, melamine was classified as a probable human carcinogen (Group 2B) by IARC [9]. No evidence of genotoxicity in vitro and in vivo and teratogenic effects have been recorded.

Formaldehyde (Fig. 4) - $\mathrm{HCHO}$ is a colorless gas with a pungent, irritating odor. Its IUPAC name is methanal. It is soluble in water and in most organic solvents.<smiles>C=O</smiles>

Fig.4. Chemical structure of formaldehyde

It enters into the body by inhalation or using an oral or dermal route. It is degraded in the liver to methyl alcohol and formic acid. A single intake of small amounts of formaldehyde does not cause acute effects. Formaldehyde damages the central nervous system and especially the superior colliculi ("little hills") in the visual nervous system. This is due to its metabolites - formic acid and methyl alcohol. It has mutagenic and carcinogenic effects [10]. In 2012, formaldehyde was classified as carcinogenic to humans (Group 1) by IARC [10].

Bamboo tableware were analyzed based on the procedures described in the guidelines of the European Reference Laboratory for Food Contact Materials (EURL-FCM) [11, 12]. The conditions for migration testing time, temperature regime, model solutions are selected according to Regulation (EC) 10/2011 [4].

\section{Matherials and methods Reagents and equipment}

The reagents used are presented in Table 2. The equipment for melamine analysis includes:

$\checkmark \quad$ ltrasonic bath with timer and heater Ultrasonic USC200TH;

$\checkmark$ Liquid chromatograph HP Agilent - Series 1050;

$\checkmark$ Column: Reverse phase LiChrosorb $250 \times 4.6(5 \mu \mathrm{m})$;

$\checkmark$ UV detector HP Agilent - Series 1050.

The equipment for formaldehyde analysis includes:

$\checkmark$ Water bath, with constantly controlled temperature;

$\checkmark$ Spectrophotometer "Spekol 11", manufactured by CARL ZEISS JENA. 
Table 2.

\begin{tabular}{|c|c|}
\hline \multicolumn{2}{|c|}{ Reagents used } \\
\hline For melamine & For formaldehyde \\
\hline $\begin{array}{ll}\checkmark & \text { Melamine - Standard Reference Material } \\
& (2,4,6 \text {-triamino-1,3,5-triazine), CAS. № 108- } \\
& 78-1) ; \\
\checkmark & \text { Acetic acid, } 96 \% \text {, Honeywell (Fluka); } \\
\checkmark & \text { Acetonitrile - Gradient grade for HPLC, } \\
\checkmark & \text { Sodium dihydrogen phosphate monohydrate } \\
& \left(\mathrm{NaH}_{2} \mathrm{PO}_{4} \cdot \mathrm{H}_{2} \mathrm{O}\right) \text { to prepare a buffer for the } \\
\text { mobile phase }\end{array}$ & $\begin{array}{ll}\checkmark & \text { Formaldehyde Certified reference material } \\
& \text { (Formaldehyde solution, CAS. № 50-00-0); } \\
\checkmark & \text { Acetic acid, 96\%, Honeywell (Fluka); } \\
\checkmark & \text { Sulfuric acid-95-97\%, Honeywell (Fluka) } \\
\checkmark & \text { Chromotropic acid }\left(\mathrm{C}_{10} \mathrm{H}_{6} \mathrm{Na}_{2} \mathrm{O}_{8} \mathrm{~S}_{2} .2 \mathrm{H}_{2} \mathrm{O}\right), \\
& \text { Merck }\end{array}$ \\
\hline
\end{tabular}

\section{Description of the samples}

All samples were purchased from different retail stores and are representative of different batches. The test was performed on 6 bamboo sets. Each set consists of 4 items - 6 bowls, 6 cups, 6 plates and 6 pairs of cutlery (fork and spoon), a total of 24 samples, shown in Figure 5 to Figure 7. The products are labeled as made of bamboo, environmentally friendly and biodegradable. The description indicates their origin (China) and declares that they are dishwasher safe.

\section{Sample preparation}

Each item was analyzed 6 times and the average value was calculated $(n=6)$. The food simulant used to extract the two monomers is a $3 \%$ acetic acid solution (model solution B [4]). Each sample was filled with the model solution up to $0.5 \mathrm{~cm}$ below the rim and exposed to it. The items are covered with watch glass and sealed with parafilm to prevent evaporation of the food simulant during their stay in the thermostat - at a controlled temperature of $70^{\circ} \mathrm{C}$ for 2 hours. The simulants from the first and second tests were discarded. The food simulant from the third exposure was analyzed for melamine and formaldehyde migration.

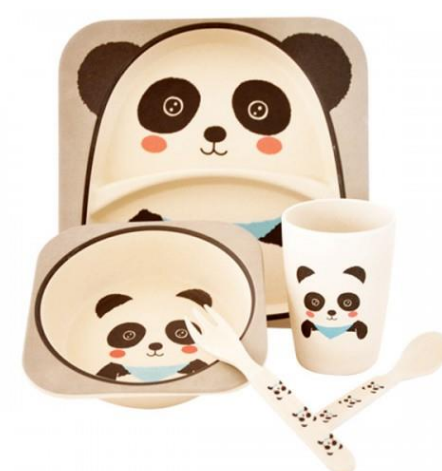

Fig.5. Image of the set "Panda" - bowl, cup, plate, utensils (fork and spoon)

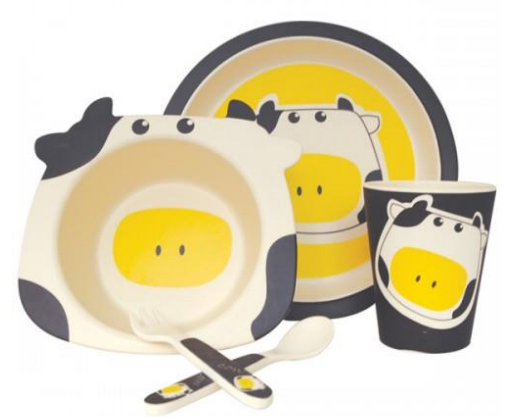

Fig.6. Image of the set "Cow" - bowl, cup, plate, utensils (fork and spoon)

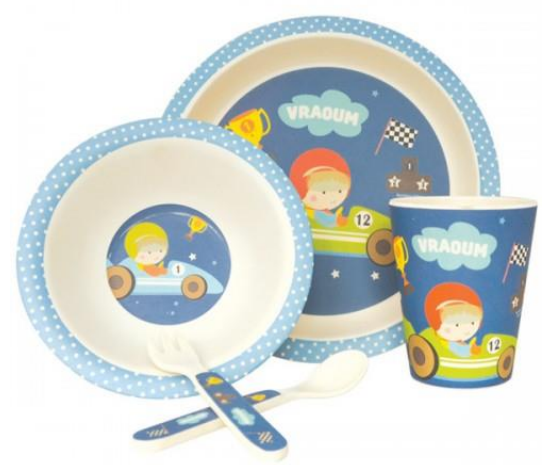

Fig.7. Image of the set "Boy" - bowl, cup, plate, utensils (fork and spoon) 


\section{Analytical instrumental methods}

HPLC-UV standardized method DD CEN/TS 13130-27:2005 "Materials and articles in contact with foodstuffs. Plastics substances subject to limitation. Determination of 2,4,6-triamino-1,3,5triazine in food simulants" was used to quantify migrated melamine in $3 \%$ aqueous acetic acid [13]. The analytical conditions for melamine analysis are as follows:

$\checkmark$ mobile phase - phosphate buffer with $\mathrm{pH}$ 6.5: acetonitrile $=(80: 20)$;

$\checkmark$ flow rate $-1.2 \mathrm{ml} / \mathrm{min}$;

$\checkmark$ UV detection at $\lambda=230 \mathrm{~nm}$;

$\checkmark$ injection volume $-50 \mu$ l.

A standardized spectrophotometric method DD CEN/TS 13130-23:2005 "Materials and articles in contact with foodstuffs. Plastics substances subject to limitation. Determination of formaldehyde and hexamethylenetetramine in food simulants" was used to quantify formaldehyde in $3 \%$ aqueous acetic acid

\section{Results and discussion}

The analyzed items of the two sets of "Panda" indicated migration of melamine, which exceeds the limit value of $2.5 \mathrm{mg} / \mathrm{kg}$ according to the European legislation 1.6 times. The highest obtained average is $(4.14 \pm 0.07) \mathrm{mg} / \mathrm{kg}$, in bowl "Panda 1". All items in the same sets show a
[14]. The analytical conditions for formaldehyde analysis are as follows: exactly $8 \mathrm{ml}$ of $75 \%$ sulfuric acid and $1 \mathrm{ml}$ of chromotropic acid were added to $1 \mathrm{ml}$ of sample, followed by heating in a water bath at $60{ }^{\circ} \mathrm{C}$ for 20 minutes and cooling to room temperature for 1 hour. The extinction of the obtained color compound is determined spectrophotometrically at a wavelength $\lambda=574 \mathrm{~nm}$.

The analytical parameters for both methods are presented in Table 3:

Table 3.

Analytical parameters

\begin{tabular}{|l|l|l|}
\hline Parameter & Melamine & Formaldehyde \\
\hline $\begin{array}{l}\text { Limit of } \\
\text { Detection } \\
\text { (LOD), mg/l }\end{array}$ & 0.5 & 0.005 \\
\hline $\begin{array}{l}\text { Limit of } \\
\text { Quantification } \\
\text { (LOQ), mg/l }\end{array}$ & 1.0 & 1.5 \\
\hline $\begin{array}{l}\text { Working } \\
\text { range, mg/l }\end{array}$ & $(1.0 \div 8.0)$ & $(1.5 \div 30.0)$ \\
\hline $\begin{array}{l}\text { Correlation } \\
\text { coefficient }\end{array}$ & $\mathrm{R}^{2}=0.9996$ & $\mathrm{R}^{2}=0.9976$ \\
\hline
\end{tabular}

migration of formaldehyde but below the specific migration limit of $15 \mathrm{mg} / \mathrm{kg}$ according to European legislation. The highest mean value of $(6.49 \pm 0.01) \mathrm{mg} / \mathrm{kg}$ was obtained with the same bowl "Panda 1". The data obtained for the Panda bamboo sets are presented in Figures 8 A) and $\mathrm{B})$.

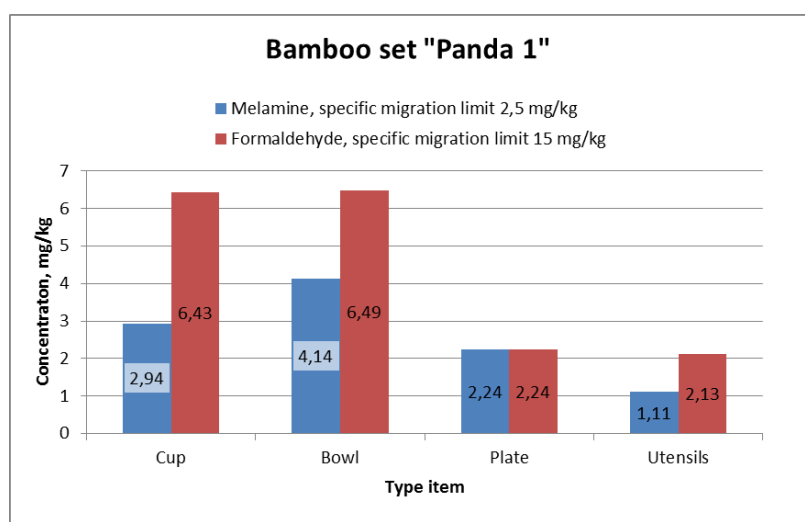

Fig.8A. Results for set "Panda 1"

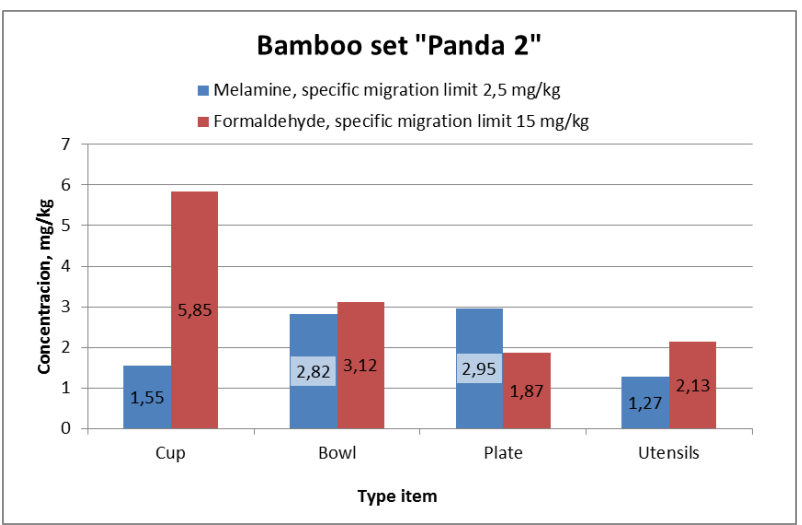

Fig.8B. Results for set "Panda 2"

Svetla Petrova PETROVA, Valentina CHRISTOVA - BAGDASSARIAN, Migration of melamine and formaldehyde from kids' bamboo dinner sets, Food and Environment Safety, Volume XX, Issue 2-2021, pag. 128 - 136 
For the sets "Cow", melamine migration was again reported for all products. The highest mean value obtained is $(5.12 \pm$ $0.004) \mathrm{mg} / \mathrm{kg}$ for the plate "Cow 2", up to twice exceeding the permissible level by $2.5 \mathrm{mg} / \mathrm{kg}$. All items in the same sets show a migration of formaldehyde. The highest mean value is $(5.91 \pm 0.01) \mathrm{mg} / \mathrm{kg}$ obtained for the bowl "Cow 2". All results for formaldehyde migration are below the permissible level of $15 \mathrm{mg} / \mathrm{kg}$ according to European legislation. The data obtained for the Cow bamboo sets are presented in Figures 9 (A) and (B).

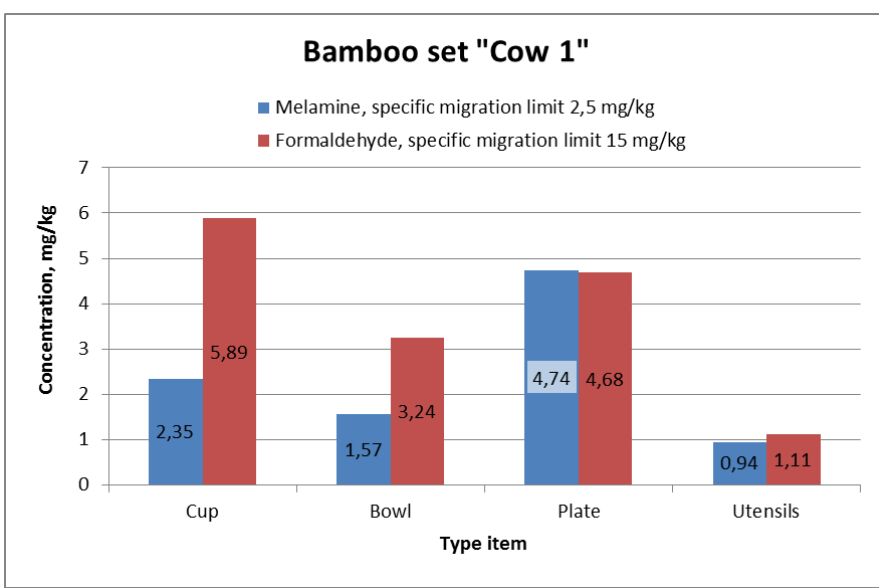

Fig. 9A. Results for set "Cow 1"

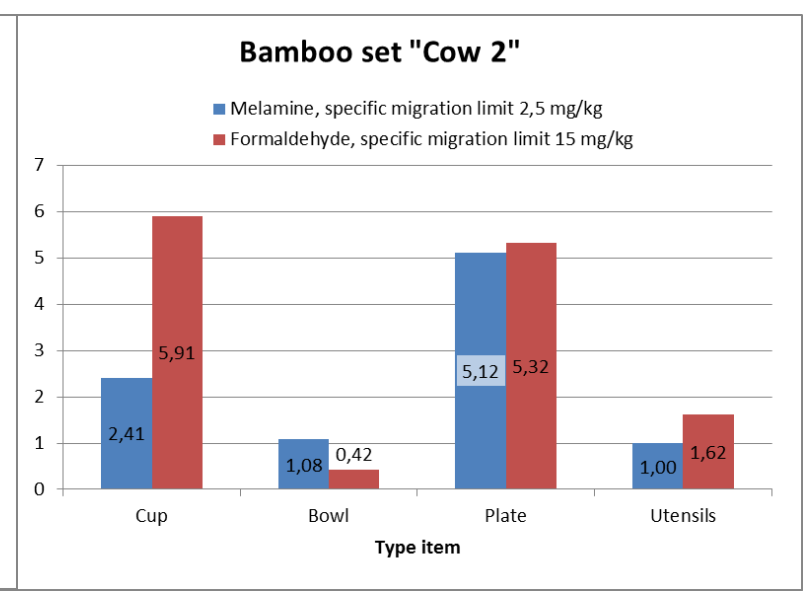

Fig.9B. Results for set "Cow 2"
For „Boy“ bamboo sets, melamine migration was again reported for all products. The highest mean value obtained is $(6.55 \pm 0.26) \mathrm{mg} / \mathrm{kg}$, for the bowl "Boy 1 ", exceeding the permissible level up to 2.6 times. Figure 10 shows the chromatograms of the highest value obtained of melamine and melamine standard solution. Migration of

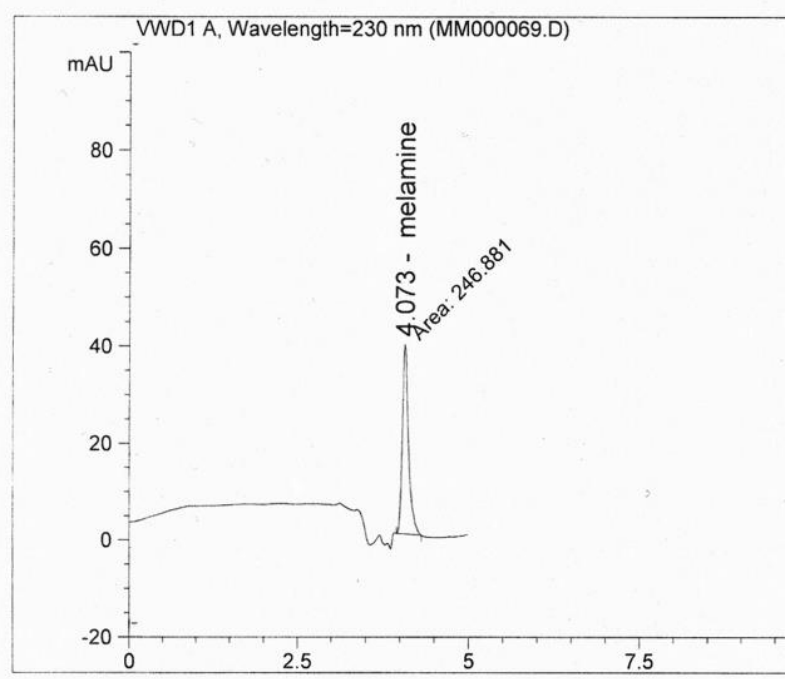

formaldehyde was detected in all sets "Boy". All formaldehyde migration results are below the permissible level of $15 \mathrm{mg} /$ $\mathrm{kg}$ according to European legislation. The highest mean value is $(10.40 \pm 0.01)$ $\mathrm{mg} / \mathrm{kg}$ obtained from the same bowl "Boy 1". The data obtained for the Boy bamboo sets are presented in Figures 11 A) and B).

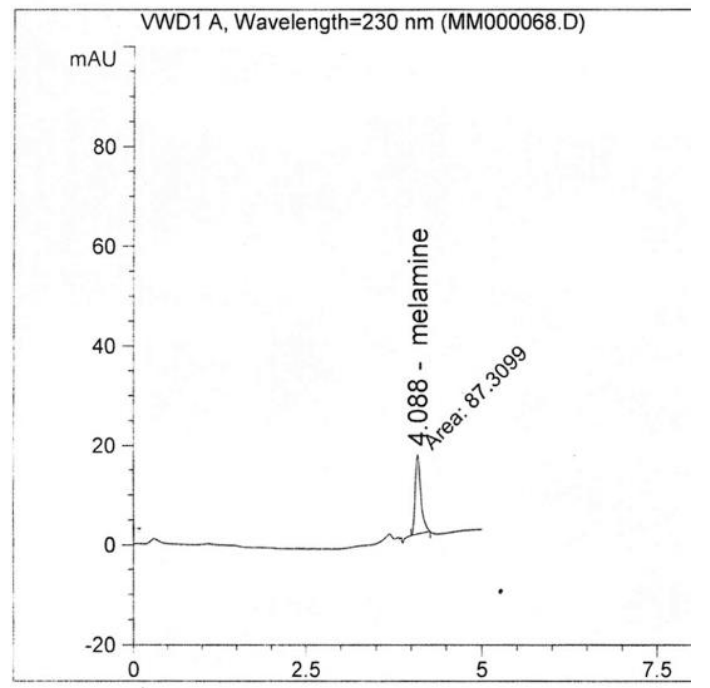

Fig.10. Chromatograms of the highest migration value obtained and melamine standard solution

Svetla Petrova PETROVA, Valentina CHRISTOVA - BAGDASSARIAN, Migration of melamine and formaldehyde from kids' bamboo dinner sets, Food and Environment Safety, Volume XX, Issue 2-2021, pag. 128 - 136 


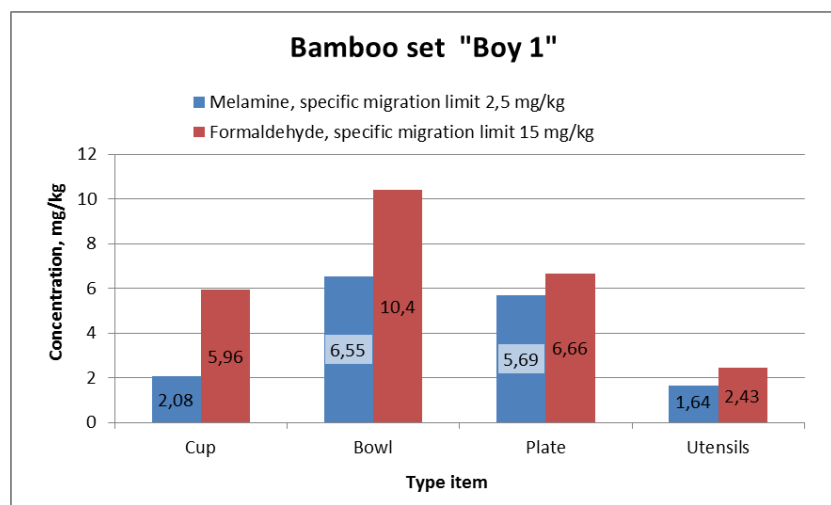

Fig. 11A. Results for set "Boy 1"

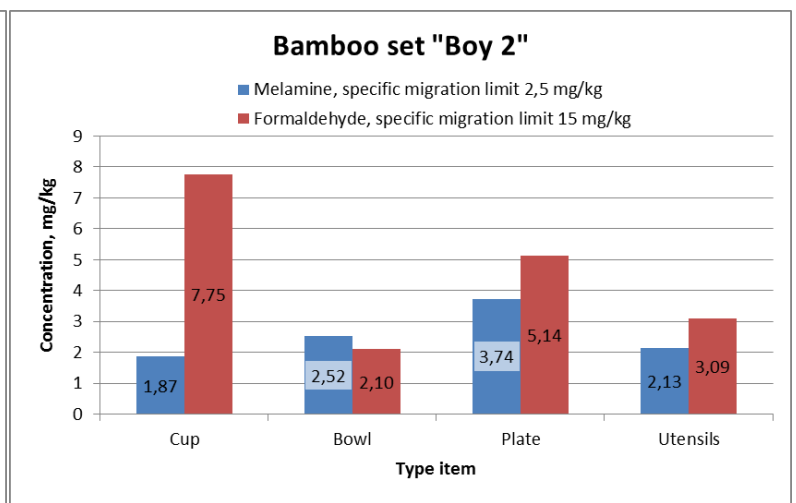

Fig. 11B. Results for set "Boy 2"
In all bamboo products studied, migration of both monomers forming melamine formaldehyde resin - melamine and formaldehyde was found. This indicates that the material from which they were made should be classified as plastic. The results obtained for both melamine and formaldehyde are scattered in a wide concentration range. This shows the inhomogeneity of the plastic material from which the individual items in the different batches are made. These results confirm the impossibility of monitoring the quality of imports of such products.

Figure 12 presents the summarized results of the performed analyzes for migration of melamine and formaldehyde by sets. In $50 \%$ of the sets, the migration of melamine exceeds the specific migration limit for the monomer up to 1.6 times. No migration of formaldehyde above the legal requirement of $15 \mathrm{mg} / \mathrm{kg}$ has been identified.

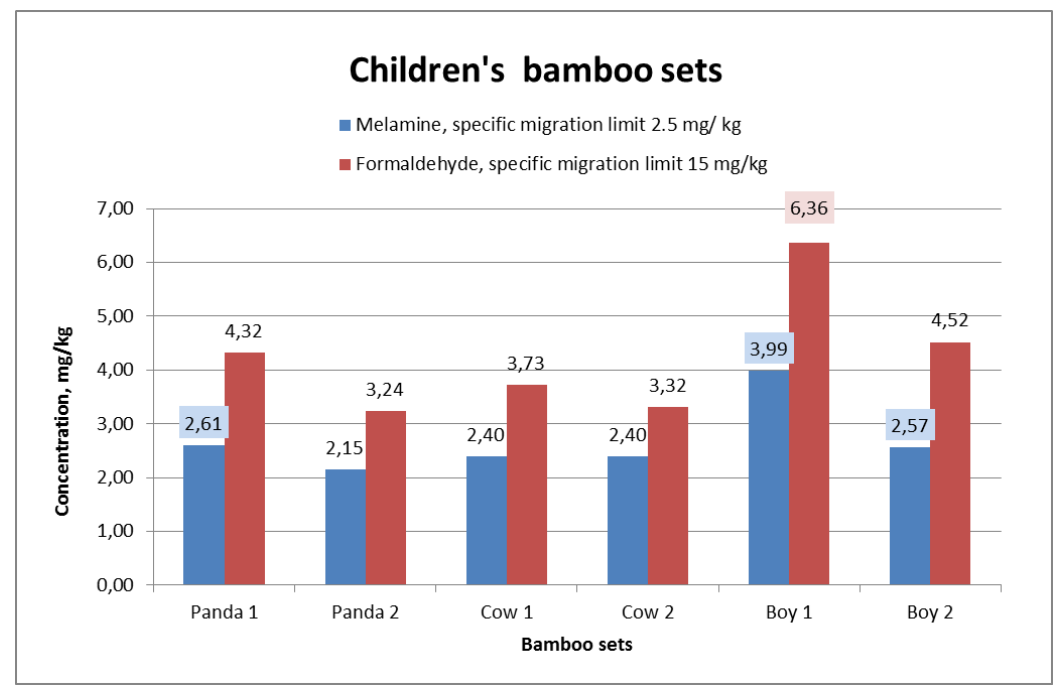

Fig.12. Results for bamboo sets

\section{Conclusion}

Migration of melamine and formaldehyde from all tested products has been proven. Melamine migration exceeds the specific migration limit (SML) in $62 \%$ of products and the highest value reaches 2.6 times SML. All formaldehyde results are within the permissible values in European legislation. 
The material from which the bamboo products are made should be defined as plastic, as it contains melamineformaldehyde resin.

Plastic products labeled as made of bamboo create a misconception in the consumer about them being "made of natural materials", "environmentally friendly", "biodegradable". In fact, although they contain bamboo fibers, they are made of plastic and are not completely biodegradable.

\section{References}

[1]. ZHANG Q. S., JIANG S. X., TANG Y. Y. Industrial utilization on bamboo: Technical report No. 26. The International Network for Bamboo and Rattan (INBAR), Peoplee"s Republic of China., 206, (2002). ISBN 962-85124-7-1. Retrieved from https://www.inbar.int/wpcontent/uploads/2020/05/1489455793.pdf [2]. BfR, Release of melamine and formaldehyde from dishes and kitchen utensils, 2011. Retrieved from https://mobil.bfr.bund.de/cm/349/release_of_melam ine and formaldehyde from dishes and kitchen utensils.pdf

[3]. Summary of discussions of the Expert Working Group on Food Contact Materials on the use and placing on the market of plastic food contact materials and articles containing ground bamboo or other similar constituents, Brussels, (2019). Retrieved from https://ec.europa.eu/food/sites/food/files/safety/doc s/cs_fcm bamboo_wg-201906.pdf

[4]. Commission Regulation (EU) No 10/2011 of 14 January 2011 on plastic materials and articles intended to come into contact with food.

[5]. Regulation (EC) No 1935/2004 of the European Parliament and of the Council of 27 October 2004 on materials and articles intended to come into contact with food and repealing Directives 80/590/EEC and 89/109/EEC.

[6]. Commission Regulation (EU) No 284/2011 of 22 March 2011 laying down specific conditions and detailed procedures for the import of polyamide and melamine plastic kitchenware originating in or consigned from the People's Republic of China and Hong Kong Special Administrative Region, China.
[7]. HSIEH T. J., HSIEH P. C., TSAI Y. H. et al., Melamine induces human renal proximal tubular cell injury via transforming growth factor- $\beta$ and oxidative stress, Toxicol Sci., 130(1):17 - 32, (2012).

[8]. YANG Y. et al., Acute low-dose melamine affects hippocampal synaptic plasticity and behavior in rats, Toxicol Lett, 214:63 - 68, (2012).

[9]. Some Chemicals That Cause Tumours of the Urinary Tract in Rodents, IARC Monographs on the Evaluation of Carcinogenic Risks to Humans, 119:274, (2019).

[10]. Chemical Agents and Related Occupations, IARC Monographs on the Evaluation of Carcinogenic Risks to Humans, 100F:628, (2012).

[11]. Technical guidelines on testing the migration of primary aromatic amines from polyamide kitchenware and of formaldehyde from melamine kitchenware, $1^{\text {st }}$ Edition [in support of Commission Regulation 284/2011 laying down specific conditions and detailed procedures for the import of polyamide and melamine plastic kitchenware originating in or consigned from People's Republic of China and Hong Kong Special Administrative Region, China] EUR24815 EN 2011, (2011). Retrieved from: https://ec.europa.eu/jrc/en/publication/eurscientific-and-technical-research-reports/technicalguidelines-testing-migration-primary-aromaticamines-polyamide-kitchenware-and

[12]. EU guidelines on conditions and procedures for the import of polyamide and melamine kitchenware originating in or consigned from People's Republic of China and Hong Kong Special Administrative Region, China European Commission., Health and consumers directorategeneral Directorate, E- Safety of the Food chain E6- Innovation and sustainability, Version 1 (2011). Retrieved from https://ec.europa.eu/food/sites/food/files/safety/doc s/cs_fcm_legis_china_guidelines_import-polymidemelamine.pdf

[13]. DD CEN/TS 13130-27:2005. Materials and articles in contact with foodstuffs. Plastics substances subject to limitation. Determination of 2,4,6-triamino-1,3,5-triazine in food simulants.

[14]. DD CEN/TS 13130-23:2005. Materials and articles in contact with foodstuffs. Plastics substances subject to limitation. Determination of formaldehyde and hexamethylenetetramine in food simulants. 